\title{
СТОСУНКИ ЧИТАЧА ТА КНИГИ В СУЧАСНОМУ СОЦІКУЛЬТУРНОМУ СЕРЕДОВИЩІ
}

\author{
С. К. Андрейчук \\ Національний університет «Львівська політехніка», \\ вул. Коновальия 4, м. Львів, Україна, 79044, \\ a_stanislav@ukr.net \\ В. I. Когут \\ Національний університет «Львівська політехніка», \\ вул. Коновальия 4, м. Львів, Україна, 79044, \\ kohut_vitaliy@ukr.net

\section{О. О. Морушко} \\ Національний університет «Львівська політехніка», \\ вул. Коновальия 4, м. Львів, Украӥна, 79044, \\ morushkoo@gmail.com
}

\begin{abstract}
У статті проаналізовано особливості взаємодії між книжкою та читачем на сучасному етапі розвитку людства. Описано рівні простору, на яких протікає комунікація між читачем та книжкою. Надано практичні рекомендації щодо пошуку і знаходження друкованої літератури під конкретного читача, спираючись на метод соціонічного аналізу. Розкрито переваги використання цього методу при практичній взаємодії читача і книжки. Використовуючи метод соціонічного аналізу можна обирати для навчання i самоосвіти таку літературу, яка буде найбільш засвоюваною будь-якою людиною. Знання власної ментальності і вміння визначати ментальність інших людей, в тому числі i авторів друкованої літератури, допомагає заощаджувати час на пошук оптимальних для нас друкованих видань. Процејнформатизації сучасного суспільства спонукатиме авторів та споживачів друкованої інформації до певної соціонічної спеціалізації, коли те чи інше видання буде орієнтованим на певний соціонічний сегмент суспільства.

Ключові слова: читач, книжка, соціокультурне середовище, соціонічний аналіз
\end{abstract}

Книга - це складова частина та головний носій загальної культури. Ї̈̈ образ складається з багатьох чинників, які несуть в собі пізнавальну, моральну, естетичну та іншу інформацію. Якою б за формою книга не була, вона стає універсальним зберігачем соціального досвіду. Книга має двоїстий і навіть багатоманітний характер. Вона може виступати і засобом збереження інформації для людей наступних поколінь, і засобом комунікації, і у вигляді товару [1].

Книга як засіб спілкування, передачі інформації і культурологічний чинник існує вже не одну сотню років. Важко переоцінити значення феномену книги в історії роз-

(C) Андрейчук С. К., Когут В. І., Морушко О. О., 2017 
витку людства. Проте вік інформаційних технологій висуває до сучасної книги нові вимоги і виклики, з якими сучасна книга просто зобов'язана справитися. Які ж з них, на нашу думку, є найсуттєвішими?

По-перше, нові часи надають нові можливості для споживачів інформаційної продукції. Інтернет заполонила величезна кількість електронних книжок, серед яких дуже легко загубитися. Очевидно, що в умовах існування інформаційного суспільства, усі ми просто зобов'язані навчитися оперативно і якісно працювати з книжками, серед величезного книжкового масиву вміти знаходити саме свої книжки, ті що допоможуть нам духовно збагатитись, допоможуть нам розкрити свій внутрішній потенціал, нададуть можливість самовираження.

По-друге, мине можемо собі дозволити занадто багато часу витрачати на пошук та усвідомлення необхідної інформації. Отже, інформативна насиченість і доступність матеріалу, викладеного у книзі, стає запорукою їі успішності серед читачів. Розповідати про найскладніші речі простою і доступною мовою - ось основна вимога потенційного читача до своєї книги.

По-третє, і це найголовніше, - ми живемо і комунікуємо у відкритому соціальному просторі, а це означає, що наша успішність в значній мірі залежить від того, наскільки швидко і вдало ми можемо доносити свої почуття і думки до оточуючих. Від інформаційного книжкового продукту, який ми споживаємо, ми також будемо очікувати отримати практичні знання з комунікації, які дозволять нам бути повноцінними і успішними представниками соціуму.

Отже, сучасна книга як інформаційний продукт, повинна бути інформативною, наочною, доступною і корисною водночас.

У процесі читання ми вступаємо в безпосередній контакт з автором книжки: погоджуємось чи не погоджуємось 3 ним, намагаємось доповнити чи уточнити деякі його твердження і думки, одним словом, вступаємо в діалог з автором.

На думку Умберто Еко, автор, створюючи текст, застосовує ряд кодів, за допомогою яких він надає певного змісту своїм висловлюванням. При цьому автор (якщо він призначає свій текст для комунікації) повинен виходити з того, що комплекс застосовуваних ним кодів - такий же, як і у його можливого читача. Інакше кажучи, автор повинен мати на увазі якусь модель можливого читача, який зможе інтерпретувати закладений зміст точно в такому ж дусі, в якому письменник їх створював [2, с. 9].

Для глибшого розуміння процесу контактування між читачем і книгою, варто згадати про теорію інформаційного метаболізму, розроблену польським вченим-психіатром А. Кемпінським. Згідно цієї теорії, зовнішні інформаційні сигнали, що приймаються психікою, уподібнюються їжі, яку для процесу енергетичного метаболізму отримує організм, тобто як їжа, необхідна для енергетичного метаболізму організму, так і інформаційні сигнали - для інформаційного метаболізму психіки. Процеси інформаційного метаболізму спрямовані на встановлення контролю над дійсністю, на досягнення можливості маніпулювати нею [3, с. 238].

3 точки зору типології, розробленої К.Г. Юнгом, кожна людина є не тільки індивідуумом і представником людського роду, але й представником певного типу інформаційного метаболізму. Можна стверджувати, що інформаційний метаболізм $є$ тим самим кодом, за допомогою якого передається інформація [4, с. 27]. 
На основі типології К.Г. Юнга та теорії інформаційного метаболізму А. Кемпінського у середині 70-х років XX ст. литовською вченою А. Аугустинавічюте була створена наука соціоніка. За визначенням самої Аугустінавічюте, соціоніка $є$ наукою про соціон, соціонну структуру суспільства, про різні типи інформаційного метаболізму і різні форми відносин між ними, про структуру і функціонування моделі інформаційного метаболізму [4, с. 33].

Згідно соціонічної теорії, існує 16 різних типів інформаційного метаболізму (ТIM). По суті, це 16 різних типів сприйняття інформації з оточуючого середовища. Отже, 3 достатньо високим степенем імовірності можна стверджувати, що в залежності від TIM автора книжки і читача, між ними будуть виникати достатньо різні взаємодії.

Цих 16 типів об'єднані у 4 соціонічних квадри. Згідно формулювання А. Аугустинавічюте, типи, що входять до однієї квадри, об'єднані між собою певною спільністю інтересів та відсутністю можливостей конфлікту. Вирізняються взаєморозумінням i виключно продуктивною і плодотворною співпрацею [4, с. 305].

Слід зазначити, що процес обміну інформацією, налагодження діалогу, взаєморозуміння між учасниками комунікації, досягнення результату спілкування відбувається у певному комунікативному просторі - середовищі, в якому протікає взаємодія ТІМів. Комунікативний простір неоднорідний: його щільність в різних місцях неоднакова, тому інформаційний обмін одних і тих же ТІМів в різних його місцях буде мати різну інтенсивність.

Визначити, на якому рівні простору протікає комунікація, допомагають два параметри:

- Протяжність простору визначає комунікативна дистанція (близька-далека);

- Проникність простору визначає щільність комунікації (глибока-поверхнева).

Таким чином, можна виділити чотири основних рівня взаємодії, на яких буде виникати контакт між автором і читачем. Це - фізичний, психологічний, соціальний та інформаційний рівні.

На фізичному рівні задовольняються природні потреби людини - в їжі, житлі, продовженні роду, виробництві та споживанні матеріальних продуктів, що характерно для щільного, матеріально опосередкованого зіткнення фізичних субстратів (носіїв) інформаційних систем.

На психологічному рівні на перше місце виходить обмін потаємною, особистісною інформацією, що йде $з$ душі. Передбачаються найдовірливіші відносини, оскільки тут людина задовольняє свої інтимно-емоційні потреби - в любові, дружбі, сім'ї, співпереживанні і т.п.

Соціальний рівень регулюється суспільними нормами, традиціями і ритуалами, законодавством, державними інститутами і т.п. Інтереси індивіда підпорядковуються інтересам соціуму. Суб’єкт соціальної комунікації виступає не як унікальна особистість, а як представник соціальної групи (тобто має певний соціальний статус і роль, відповідну статусу). На цьому рівні людинжадовольняє потреби в кар'єрі, освіті, праці і повазі, престижі.

Інтелектуальний (інформаційний) рівень. Здійснювати глибоку комунікацію без дотику з іншою стороною можна, лише перенісши весь інформаційний обмін всереди- 
ну себе, в свій мозок. При цьому посилено працюють пам’ять і уява. Тільки на цьому рівні можна звертатися до глибин своєї підсвідомості і добувати відомості, накопичені поколіннями людей. На цьому рівні людина задовольняє потреби в актуалізації, розкритті своїх талантів і здібностей, творчості, пізнанні і самовдосконаленні [5, с. 28-29].

Останні статистичні дослідження свідчать, що читання як таке зазнало суттєвих змін. Використання сучасних носіїв інформації, значне збільшення обсягів інформації, 3 якою доводиться мати справу, зумовлюють фрагментарність сприйняття, переважання картинки, а не слова, неспроможність сучасного читача сконцентруватися на довгому тексті. При цьому одночасно зросла швидкість сприйняття інформації [6, с. 87]. Тому для кращого розуміння і сприйняття тексту важливо, аби читач не вступав в конфлікт 3 автором, а навпаки, максимально ототожнював себе 3 ним, виходив 3 ним на синергетичний зв'язок.

Ще однією характерною рисою сучасного читача $є$ відкритість до нових технологій, визнання цінностей самореалізації, цінності кар'єрного зростання. Це спонукає до активного споживання інформації, але насамперед до такої, яка надає можливість самовдосконалюватись, досягати нових висот, отримувати нові знання, які в майбутньому можуть принести практичну користь [7, с. 32].

Отже, для актуалізації своїх можливостей слід знати не лише те, чого ти хочеш досягнути, але й можливі шляхи реалізації поставленої перед собою мети. А це стає можливим лише тоді, коли ти вмієш вірно оцінити свої потенційні можливості, закладені природою. Без спеціальних знань з практичної психології, одним з розділів якої $\epsilon$ і соціоніка, на сьогоднішній день це практично неможливо.

Не можна оминути стороною ще один аспект, що характеризує формування сучасного читача - глобалізацію, в тому числі і соціокультурного простору. На думку українського науковця К. Серажима, глобалізація, з одного боку несе в собі чимало позитивного, створює передумови для інтелектуального і технологічного прориву, забезпечує комунікативний і культурний зв'язок з усім світом, з іншого - призводить до руйнування традиційних національних культур [8, с. 44]. На нашу думку, глобалізацію культурного простору теж можна використати на свою користь.

Сучасні дослідження показали, що не тільки кожна людина має свою персональну ментальність. Також кожен народ чи нація володіє інтегральним типом, який включає до себе певний набір рис і якостей, найбільш властивих цій нації. Отже, знаючи особливості ментальності тієї чи іншої нації, ми з високою долею достовірності можемо знайти серед творів, що належать представникам цієї нації саме ті, що відповідатимуть нашим смакам і уподобанням, з точки зору нашої психологічної сумісності з інтегральним типом обраної нації. Тому володіння подібною інформацією надає їі носію значних конкурентних переваг перед тими, хто цими знаннями не володіє.

Внаслідок стрімкої інформатизації суспільства в останні роки за допомогою читання людина опрацьовує більший, ніж раніше, обсяг інформації. При цьому, зараз у читача менше можливостей і бажання для вдумливого, глибокого читання, яке, на думку експертів, є важливим фактором розвитку суб'єктності індивіда [9, с. 9].

Особливістю соціоніки є її логічна стрункість і технологічність, внаслідок чого зацікавлена людина може почати займатись практикою буквально через кілька днів 
після ознайомлення з азами теорії. Знання типових ознак дозволяє краще зрозуміти конкретну людину, пізнати ії унікальну індивідуальність [10, с. 9].

Спроби підвести відмінності між людськими індивідуальностями до певних категорій на основі типових відмінностей робились ще $з$ давніх часів. Зокрема такі спроби здійснювались і в галузі медицини [11, с. 608], а також не оминули вони і соціологію $[12,13,14]$.

Вивчаючи особливості психологічних проявів людей, Юнг побудував свою типологію особистості. Він ввів принципово нові поняття, які поклав в основу типології, i це дозволило застосувати методи об'єктивного аналізу до вивчення людської психіки. Введені ним дихотомічні терміни «екстраверсія-інтроверсія», «раціональність-ірраціональність», «мислення-почуття», «відчуття-інтуїція» сьогодні широко застосовуються в повсякденному житті. Вони навіть встигли набути таких відтінків значення, які в них Юнг і не вкладав $[15$, с. 8$]$.

Історично сформувалися чотири основних управлінських культури - американська, європейська, японська та радянська. Кожна з основних управлінських культур має свої характерні особливості, якими вона відрізняється від інших. За допомогою використання методу соціонічного аналізу було встановлено, що європейська управлінська культура базується на квадральних цінностях першої квадри; радянська - на квадральних цінностях другої квадри; американська - на квадральних цінностях третьої

квадри; японська - на квадральних цінностях четвертої квадри. Таким чином, основні управлінські культури охоплюють увесь соціонічний спектр [16, с. 55]. Отже, знаючи ментальні особливості того чи іншого народу, йогохильність до певної управлінської культури, можна з достатньою долею імовірності стверджувати, що автори, які живуть і працюють у соціокультурних умовах цих управлінських культур, будуть їм близькими по духу. Співвідносячи свій особистий тип з інтегральним типом нації також можна прогнозувати на якому з рівнів буде проходити комунікація конкретної персони з культурним надбанням конкретної нації, в т. ч. і з художньою чи науковою літературою цього народу.

Отже, підсумовуючи сказане вище, можна зробити наступні висновки:

1. Використовуючи метод соціонічного аналізу можна обирати для навчання і самоосвіти таку літературу, яка буде найбільш засвоюваною будь-якою людиною.

2. Знання власної ментальності і вміння визначати ментальність інших людей, в тому числі і авторів друкованої літератури, допомагає заощаджувати час на пошук оптимальних для нас друкованих видань.

3. Процес інформатизації сучасного суспільства спонукатиме авторів та споживачів друкованої інформації до певної соціонічної спеціалізації, коли те чи інше видання буде орієнтованим на певний соціонічний сегмент суспільства.

Звичайно, автори статті не претендуютна істину в останній інстанції. Проте вони глибоко переконані в тому, що викладені вище думки мають право на існування і на застосування в процесі щоденної життєдіяльності людини. 


\section{СПИСОК ВИКОРИСТАНОЇ ЛІТЕРАТУРИ}

1. Біличенко О. Л. Культурно-виховна роль книги в умовах формування інформаційного суспільства : автореф. дис. канд. пед. наук: 07.00 .08 / О. Л. Біличенко; Харк. держ. акад. культури. - Харків, 2000.

2. Эко Умберто. Роль читателя. Исследования по семиотике текста. - Москва: CORPUS; 2016.

3. Кемпинский А. Меланхолия. - Санкт-Петербург : Наука, 2002.

4. Аугустинавичюте А. Соционика. Введение. - Москва: АСТ, 1998.

5. Струкчинская E. М. Соционика: учебное пособие / Е. М. Струкчинская, С. 3. Струкчинский, Е. В. Разгоняева. - Бийск: Изд-во Алт. гос. техн. ун-та, 2010.

6. Листвак Г. Б. Дослідження читання в Україні: результати і значення / Г. Б. Листвак // Наукові записки [Української академії друкарства]. Серія : Соціальні комунікації. 2015. - № 2.

7. Крайнікова Т. Друкована книга і читання в сучасній культурі медіаспоживання: peцептивний аналіз / Т. Крайнікова // Бібліотечний вісник. - 2013. - № 2.

8. Серажим К. С. Культура читання в Україні / К. С. Серажим // Наукові записки Інституту журналістики. - 2014. - Т. 55.

9. Читання в Україні: результати дослідження читацьких звичок та ставлення до читання, проведеного у 2013-2014роках. -Джерело доступу: httpbookplatform.org/images/activities $/ 275 /$ brochurereadingfi nalprint.pdf.

10. Каганець I. В. Психологічні аспекти в менеджменті: типологія Юнга, соціоніка, психоінформатика / I. В. Каганець. - Київ-Тернопіль: Мандрівець-Port-Royal, 1997.

11. Юнг К. Психологические типы / К. Юнг. - М.: Университетская книга: АСТ, 1998.

12. Теннис Ф. Общность и общество / Ф. Теннис // Социологический журнал. - Москва, 1998. № 3/4. - С. 207-229.

13. Зиммель Г. Избранные работы / Г. Зиммель. - М.: Ника-Центр, 2006. - 437 с.

14. Steven G. L. Social Structural Effects on Emotion // Research Agendas in the Sociology of Emotions / Ed. by T. D. Kemper. - Albany: State University of New York Press, 1990. P. 134-179.

15. Бескова Л. А. Я и все остальные. Начала соционики /Л. А. Бескова, Е. А.Удалова Москва: ГроссМедиа, РОСБУХ, 2004.

16. Морушко О. О. Основні управлінські культури: соціонічний аналіз / О. О. Морушко, А. Л. Висоцький // Теоретичні і практичні аспекти економіки та інтелектуальної власності: збірник наукових праць. - ПДТУ. - Маріуполь, 2016. - Вип. 1, Т. 1. 


\title{
THE RELATIONS OF READER AND BOOKS IN CONTEMPORARY CULTURAL ENVIRONMENT
}

\author{
S. K. Andreychuk \\ Lviv Polytechnic National University, \\ Konovalcya Str., 4, Lviv, Ukraine, 79044, \\ a_stanislav@ukr.net \\ V. I. Kohut \\ Lviv Polytechnic National University, \\ Konovalcya Str., 4, Lviv, Ukraine, 79044, \\ kohut_vitaliy@ukr.net \\ O. O. Morushko \\ Lviv Polytechnic National University, \\ Konovalcya Str., 4, Lviv, Ukraine, 79044,
}

The book is an integral part and the main carrier of the common culture. It image consists of many factors that carry cognitive, moral, aesthetic and other information. It can act as a means of preserving information for people of the following generations, both as a means of communication so in the form of goods.

The modem book as an information product should be informative, visible, accessible and useful at the same time. While reading we enter into direct contact with the author of the book: we agree or disagree with him, try to supplement or clarify some of his statements and thoughts, in one word, we enter into dialogue with the author. To understand deeper the process of interaction between the reader and the book the theory of information ex change should be remind, which was developed by the Polish scientist psychiatrist A. Kempinsky. Following the point of view of the typology developed by K.G. Jung, each person is not only an individual and a representative of the human race, but also a representative of a certain type of information metabolism. It can be argued, that information metabolism is the same code by which information is transmitted.

Based on the typology of K.G. Jung and the theory of information metabolism of A. Kempinsky in the mid 70-ies of the twentieth century the science of socionics was created by Lithuanian scientist A. Augustinavichiute. According to the Socionic theory there are 16 different types of information metabolism (TIM). Actually, these are 16 different types of information's perceptions from the environment. Consequently, can be argued with a sufficiently high degree of probability that, depending on the TIM of the author of the book and the reader, there will be quite different interactions between them.

Modem studies have shown that not only every person has his own personal mentality. In addition, every nation or folk has an integral type that includes a certain set of traits and qualities that are the most peculiar to this nation. Therefore, knowing the peculiarities of the mentality of a particular nation, we can fi nd out. with the high degree of authenticity, among the works belonging to the representatives of this nation those that correspond to our tastes and preferences in terms of our psychological compatibility with the integral type of the selected nation. Therefore, the possession of such information gives it's carrier of signifi cant competitive advantages to those who do not possess this knowledge.

So. summing up we can draw the following conclusions:

1. Using the method of socionic analysis you can choose for study and self-education such literature, which will be most assimilated by any person.

2. Knowledge of own mentality and ability to determine the mentality of other people, including the authors of printed literature, helps to save time for fi nding the best print media for us.

3. The process of informatization of modem society will encourage authors and consumers of printed information to a certain socionic specialization, when a particular edition will be oriented to a certain socionic social segment.

Keywords: reader, book, socio-cultural environment, socionic analysis 